\title{
Development of PBL-STEM-based E-LKPD to improve students' science literacy skills on reaction rate materials
}

\author{
Rina Safitri ${ }^{1, *}$, Haryanto ${ }^{2}$ and Harizon ${ }^{2}$ \\ ${ }^{1}$ Chemistry Education Study Program, Postgraduate, Jambi University, Jambi 36361, Indonesia \\ ${ }^{2}$ Departemen of Chemistry Education, Jambi University, Jambi 36361, Indonesia \\ *Corresponding author: RS, rinatambunan811@gmail.com
}

DOI: 10.24114/jpkim.v13i2.26980

Article history:

Received: 02 July 2021

Revised: 10 July 2021

Accepted: 16 July 2021

\begin{abstract}
The development model used is Research \& Development which adopts the Lee \& Owens development model. The product to be developed is E-LKPD using 3D Pageflip Professional software. 1. The procedure for developing E-LKPD with the PBL-STEM approach in improving scientific literacy skills on the reaction rate material for students. The research procedure consists of five stages, namely analysis, design, development, implementation, evaluation. Research results (1) The analysis includes media analysis, student characteristics analysis, technology analysis, situation analysis, and data analysis. (2) Design includes determining the development team, compiling a development schedule, making flowcharts and making storyboards. (3) Development includes making a product which is then validated by a team of experts until it is validated. (4) Implementation, at this stage a product assessment is carried out by 2 chemistry teachers to see the agreement between the two teachers on the product developed through the kappa test, one-on-one trial with 2 groups of respondents consisting of 3 students in each group, small group trial with two groups of respondents carried out at MAN 2 Jambi City. This trial is not conducted face-to-face, but online (5) Evaluation, which is carried out at each stage is ongoing. The conclusion in this study is that the ELKPD development procedure is in accordance with the 5 stages of the Lee \& Owens development model.
\end{abstract}

Keywords: E-LKPD, PBL-STEM, Science literacy skills

\section{Introduction}

Scientific literacy has become the most discussed topic by academics and practitioners in the world of education. This is based on the components of scientific literacy that must be owned by every individual so as to create a modern society that is scientifically literate both in terms of nature and application. According to Laugksch (2000) states that scientific 
literacy is an understanding of science and its application in the environment. Furthermore, the American Association of Advancement of Science (AAPS, 1989) in Ogunkola (2013) explains that scientific literacy is related to the natural world that is literate towards technology, mathematics, and science that are interdependent on each other; understand the concepts and principles of science; have the capacity to think scientifically; understand that science, mathematics, and technology are human endeavors; and knowing the impact of its advantages and disadvantages; and able to use scientific knowledge for individuals and social communities. OECD (2018) also revealed that scientific literacy is the ability to respond to issues related to science (chemistry, biology, physics) that are needed to find solutions to social, environmental, and social problems. complex economy. Based on this definition, scientific literacy can make students aware and skilled in solving science problems in their environment, skilled in making businesses related to science, and have an impact on improving the quality of human resources and able to improve the social and economic life of a country.

Based on PISA data (OECD, 2018) the results of the evaluation of the scientific literacy test of Indonesian students decreased compared to PISA in 2015 in all aspects (reading, mathematics, and science). Mathematics decreased by 7 points, science decreased by 7 points. and reading decreased to 26 points. This causes Indonesia to be still in the top ten from the bottom. This ranking is a benchmark that Indonesian students do not have the skills to interact and have not been able to solve science problems well. The same thing was expressed by (Saija, 2019) stating that the level of scientific literacy in the field of chemistry is still in the medium category with the lowest aspect being the context aspect of $55.30 \%$.

This is supported by the results of previous research studies that have been carried out by previous researchers at one of the Jambi City Public High Schools. From the results of the analysis of deficiencies in the study, it was found that several things were the cause of the low scientific literacy of students, namely: 1 ) it was difficult for students to understand chemical material, especially the reaction rate of the subsection of the reaction rate equation (65.7\%) and the reaction order (51.4\%); 2) students' lack of interest in reading on the given science problems; 3 ) the evaluation questions given are not in accordance with the standards of scientific literacy questions; 4) there are deficiencies in the LKPD components used and are not in accordance with the scientific literacy aspect to be measured.

In addition to these factors, several factors that cause students' low scientific literacy are learning resources that are not relevant to the socio-cultural environment (Nadhifatuzzahro et al. 2015); Teacher Ability (Fakhriyah et al. 2017) the limited ability of students in presenting data with graphs/tables (Rahayu, 2015); and students are not used to working on scientific literacy questions (Sariati, 2013) errors in the selection of learning models and methods, inadequate learning facilities and facilities, minimal learning resources, and inappropriate teaching materials (Fitriani et al. 2017; Silaban, 2021).

In essence, LKPD is one of the media that can stimulate students' cognitive, affective, and psychomotor development. (Lee, 2014) explained that LKS are able to invite students to build their knowledge through the available questions, directing students to act independently and actively, LKS designed in an appropriate format are able to improve student literacy, with the LKS the teacher's task becomes easier and easier. teachers can make time for students who need it most (McDowell \& Waddling, 1985) 
In the era of industry 4.0 which emphasizes the availability of learning resources in digital form, the development of LKPD is not limited to print media. Based on research conducted (Apriliyanti, 2019), LKPD can be developed into electronic form. Electronic LKPD has several advantages compared to printed LKPD, namely accessible, colorful, available active learning videos. However, both printed and digital LKPDs will have no effect on students if they are not prepared following the rules for preparing good and correct LKPDs. A good LKPD must meet construction, technical, and didactic requirements. Construction requirements include requirements relating to the use of language, sentence structure, vocabulary, level of difficulty and clarity which can essentially be understood by students, while didactic requirements mean that the worksheets must meet effective principles. These effective principles include the use of approaches, models, methods in preparing LKPD. In order for the electronic LKPD to be developed to have a useful effect for students, the electronic LKPD must be built based on approaches and learning models that are in accordance with the characteristics of students. The approach to events in everyday life is very suitable to be used as a flow for compiling LKPD so that students can easily understand it.

$\mathrm{PBL}$ is an interdisciplinary learning model, because PBL helps construct or grow certain competencies by using problems as a stimulus as well as the focus of student learning (Boud, 1993). According to (Hmelo-Silver, 2004), problem based learning helps students to learn actively because the situation in PBL deals with problems that exist in everyday life and makes students responsible for the learning they receive. Dischino et al. (2011) also argues that the problems contained in PBL are unstructured (encouraging students to think critically), student-centered, the teacher acts as a facilitator or tutor, and authentic (the opinions generated are purely based on the problems provided), as well as based on real problems. Several studies have shown that PBL can increase creativity (Birgili, 2015), critical thinking (Abubakar \& Arshad, 2015), problem-solving skills (Valdez \& Bungihan, 2019), highlevel thinking (Mujasam et al. 2018), communication skills (Iftitahurrahimah et al. 2020), collaboration (Fitriyani et al. 2019), and the ability to understand oneself (self-direction) (Malan \& Ndlovu, 2014), and Science Literacy skills (Imaningtyas et al. 2016).

Problems in PBL can be combined from various fields such as science, technology, engineering, and mathematics (STEM). PBL combined with a STEM environment is able to create real life learning in the classroom. It is agreed by (Ariani et al. 2019) that the application of the PBL model with a STEM approach is able to foster the creativity of students through a problem-solving process that is integrated with science, technology, engineering, and mathematics. The main goal of STEM education is for learners to integrate experiences from various fields of science in solving practical problems (Yuliati et al. 2018). (Afriana et al. 2016) also said that learning science in the context of technology and design has the potential to increase scientific literacy. Based on the description of the problem above, the researcher wants to raise the theme of developing E-LKPD based on the STEM approach. The designed E-LKPD will contain learning content in the form of text, images, videos, and animations to add and improve student learning resources and can be additional teaching materials for teachers.

\section{Methods}

2.1 Development style 
The development model used in this study is a research and development model that adopts the Lee \& Owens development model (Lee \& Owens, 2004). In this research, the product to be developed is in the form of a Student Worksheet (e-LKPD) using 3D Pageflip Professional software. The sampling technique used is purposive sampling with the criteria that students have used interactive media and have applied the PBL model.

\subsection{Development procedure}

The research and development procedure in the Lee \& Owens model consists of five stages, namely assessment/analysis which includes needs assessment and front-end analysis, design, development, implementation, evaluation. The major procedures for developing electronic worksheets using the Lee \& Owens development model are (Fig 1).

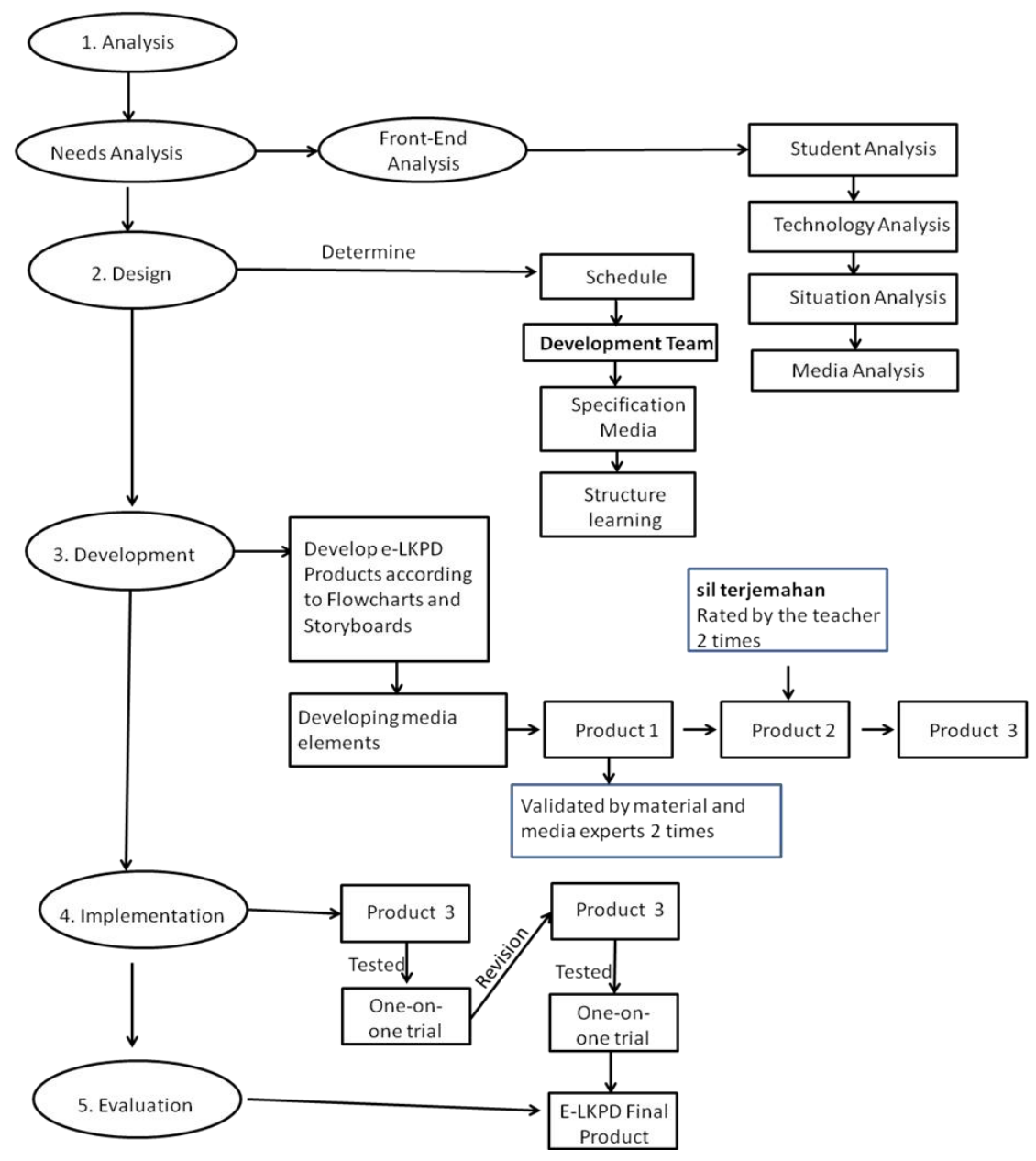

Fig 1. Electronic LKPD development procedure (Lee \& Owens, 2004)

\subsection{Data analysis techniques}

Qualitative data analysis techniques are carried out using analysis techniques and percentages. Meanwhile, quantitative data analysis techniques are in the form of questionnaire and test scores. Questionnaire scores are in the form of assessments for media experts, material experts, and small groups by calculating the percentage of answers. The test (post-test) is an assessment for students by calculating the percentage of learning outcomes. 


\section{Results and Discussion}

The development of PBL-STEM-based E-LKPD media for the reaction rate material in this study used the Lee \& Owen model which consisted of 5 stages, namely: Analysis, Design, Development, Implementation, and Evaluation. evaluation).

\subsection{Analysis stage}

Based on the observations obtained regarding the needs of teachers and students for learning media, it can be concluded that teachers and students need a medium that is easy to use for a long period of time and can interact through the media well. data collection is done by means of interviews and questionnaires.

From the results of the interview, the teacher wanted a renewal in conventional teaching materials to become more modern and valuable. So that the existence of these teaching materials can deepen students' understanding and scientific literacy is also increasing. The teaching materials in question are interactive multimedia. This is because interactive multimedia is fast in responding to users and can be used independently and controlled by students. In addition, in the learning process based on interviews.

The teacher once asked students to discuss scientifically, but the discussions that took place in class had not been created scientifically. This indicates that the scientific literacy of students has not yet emerged. Students who have literacy skills are able to recognize scientific concepts, are able to describe problems in a scientific manner, and are able to apply the knowledge that has been obtained. This will have an impact on meaningful learning outcomes for students. This is reinforced by (Fitriani et al. 2017) which states that someone who is proficient in understanding science based on evidence and involving scientific processes can finally be applied in people's lives. After interviewing the teacher, the developer also distributed questionnaires to students to find out what media students needed.

a. Analysis of student characteristics on chemistry (Student analysis)

Based on the results of the student questionnaire above, it was found that $61.2 \%$ of students considered that learning chemistry was categorized as difficult. And as many as $50 \%$ of students considered the reaction rate material to be difficult, especially in the submaterial of Collision Theory and Order of Reaction with the same percentage of $66.7 \%$. This is in accordance with the opinion (Hakimah et al. 2021) where students often experience misconceptions about the reaction order material. Students often misinterpret the relationship between reaction rates and reactant concentrations so that students often bring up wrong understandings. Furthermore, students also experience difficulties in understanding the material, understanding concepts and understanding questions where the average percentage is $55.6 \%$.

In addition to providing an assessment of the difficulties experienced, students also provide opinions on how they should be able to overcome these difficulties. From the data above, it is known that $100 \%$ of students look for solutions via the internet. This is commonplace where the internet is easier to access compared to other media. This is also agreed by (Setiyani, 2010) which revealed that the Internet has several benefits including interactive communication, access to experts, access to libraries, assisting scientific research and development, data exchange, and collaboration. 


\section{b. Media analysis and learning resources}

Based on the results of the questionnaire above, it can be seen that students use more learning resources or learning media such as worksheets and the Internet. This indicates that students prefer learning resources that are lighter and easier to carry anywhere. Furthermore, as many as $77.7 \%$ of students often use electronic media for learning, even $94.4 \%$ of students agree that they can better understand learning through electronic media. In line with the statement (Laili, 2019) which states that electronic media in the form of emodules can help students learn independently and can measure their own level of understanding. Furthermore, all students agreed to develop a complete chemistry learning multimedia containing materials, videos, and animations. This is the basis for the development of electronic teaching materials with the type of LKPD based on multimedia on the reaction rate material.

c. Technology analysis

Based on the data above, it was found that as many as $94.4 \%$ of students have laptops, it can be concluded that students are able to use technology. What's more, $100 \%$ of students already have Android, where ownership of Android is also very useful for students to access various learning materials that will later be developed.

d. Situation analysis

The situation in question is regarding the availability of technology and resources in accessing learning media. This is due to the COVID-19 pandemic situation which makes it impossible for students to attend face-to-face. Thus, students are required to be able to have e-lkpd, smartphones, and internet quota. Based on the results of the analysis of the questionnaire above, it can be stated that students often use electronic media as learning media. And all students agreed to develop interactive learning media, where the media can provide a reciprocal response when used. All students are also interested in using learning media through the 3D Pageflip application which can collect all media in one application. This makes it easier for students to obtain valid and reliable information.

\subsection{Design stage}

At the design stage, several activities were carried out as follows:

a. Determination of the development team

To develop an e-LKPD based on PBL-STEM reaction rate material, a development team is needed. The development team consists of:

1. e-LKPD developers, namely researchers

2. Supervisor: Supervisor I : : Dr. Haryanto, M.Kes

Advisor II : Dr. Harizon, M.Si

3. Material expert validator : Dr. Ngatijo, M. Si

4. Media expert validator: Prof. Dr. rer. Nat. Muhaimin, M. Si

5. Assessment of 2 chemistry teachers by : Dra. Nurnas, M.Pd and Dra. Irwinda

6. User responses of 2 groups in a one-on-one trial with 3 students in class XI MIA 1 and XI MIA 4 at MAN Jambi City

7. User responses in 2 groups with 9 students in class XI MIA 1 and Class XI MIA 2 at MAN Jambi City

b. Determination of product development schedule 
In determining the development schedule, the processes that occur are as follows:

1. Drafting e-LKPD.

2. Determine the material to be developed into an e-LKPD product based on PBL-STEM.

3. Draft e-lkpd.

4. Completing the manufacture of e-lkpd by validating several experts and respondents rather than the product to be developed.

c. Flowchart making

At the design stage, the developer makes a flowchart and storyboard, then it is redeveloped into an initial prototype.

3.3 Development stage

a. Material collection

Material development to develop PBL-STEM E-LKPD on the reaction rate material was carried out for 3 weeks. The collection of this material starts from:

1. Looking for relevant learning resources such as materials, fast reaction videos, and flash animations.

2. Looking for a background design that will be used on e-lkpd

3. Collection of pictures related to the material of reaction rates such as the process of fast or slow reaction rates, examples of the influence of reaction rate factors

4. Installing 3D pageflip to a laptop so that it is easier for developers to develop e-lkpd

b. Pageflip professional 3D product development

The steps for developing professional 3D pageflip software are as follows:

1. The developer first makes the E-LKPD design in Ms. Power point. Ms. Powerpoint was chosen by the developer because it is easier to adjust the design according to the desired layout. The design layout is adapted to images, text, and videos (Fig 2).

2. After designing and saving the E-LKPD prototype file in Ms.Powerpoint, the developer also saves the prototype in PDF format. The goal is that the E-LKPD prototype can be imported into a professional 3D pageflip application (Fig 3).

3. Open the $3 \mathrm{D}$ pageflip professional application by double-clicking the application icon shortcut on the desktop like this.

4. After that, the application will display the start page as Fig 4

5. Click the Try button, then the app will direct the user to import the file (Fig 5).

6. Click the "Create New" button. Files imported into $3 \mathrm{~d}$ Pageflip Professional can be in imago fnrmats such as .jpeg, .png, .gif, flash, video, or PDF (Fig 6).

7. Click Bronse... to select a file from the computer, then select the file storage folder to be used in e-lkpd (Fig 7).

8. Select a file to import. After that click the OK button and wait until all the files are imported into 3D pageflip professional. Then, the application will run the pdf in the form of a flipbook (Fig 8).

9. If all files have been imported, then adjust the flipbook background on the design settings menu.

10. After everything is done, the last step is to publish/convert the file into a format that can be accessed via a computer or android device. If you want to open the file on a computer, you can choose the exe format according to the Fig 9 . 
If you want to open a file on an Android device, the file can be published in 3DP format.

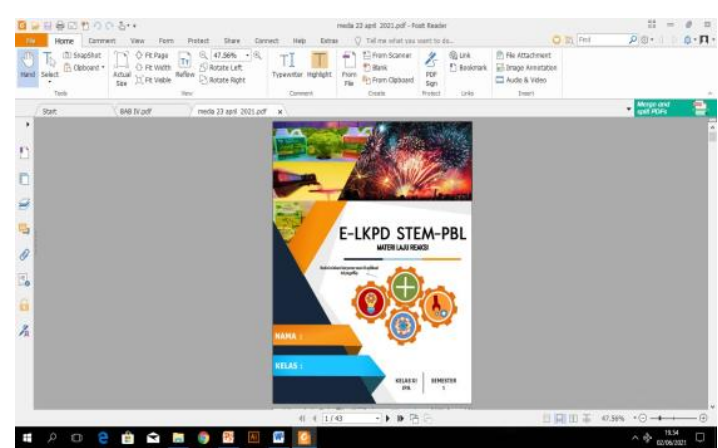

Fig 2. Initial Display of Ms. Powerpoint

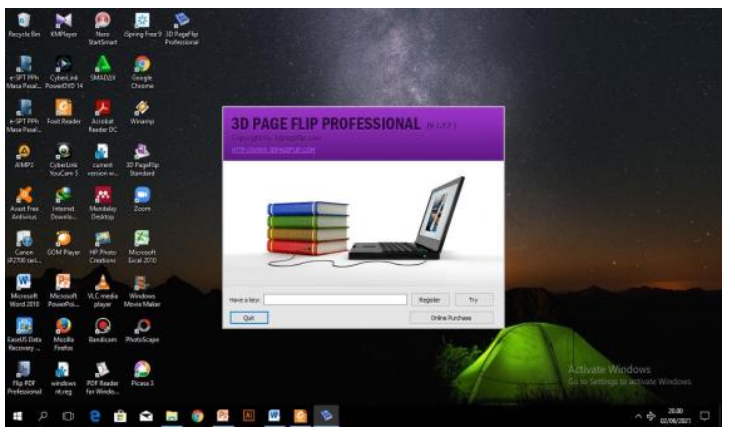

Fig 4. Initial view of the 3D pageflip Professional application

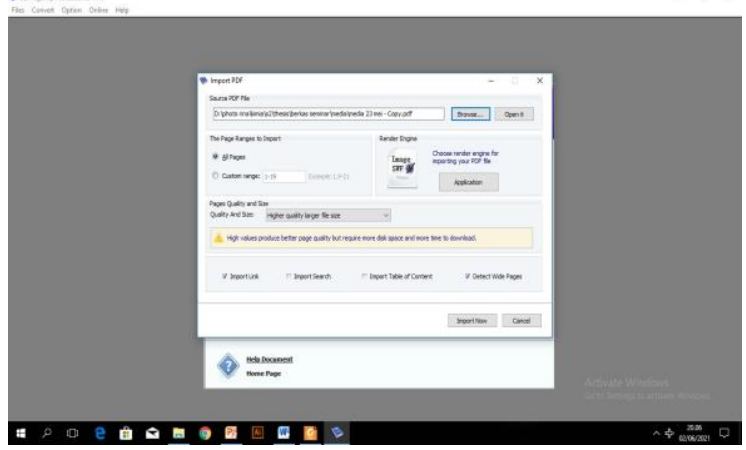

Fig 6. Steps of Importing E-LKPD Prototype Files

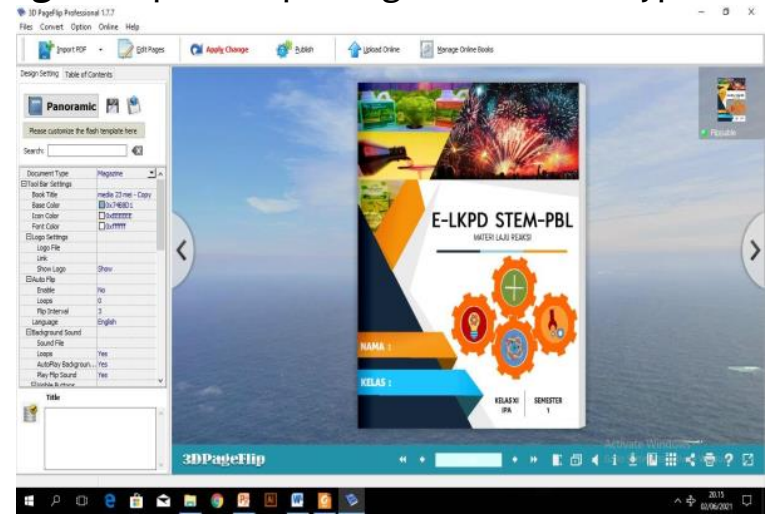

Fig 8. The Process of Importing Files

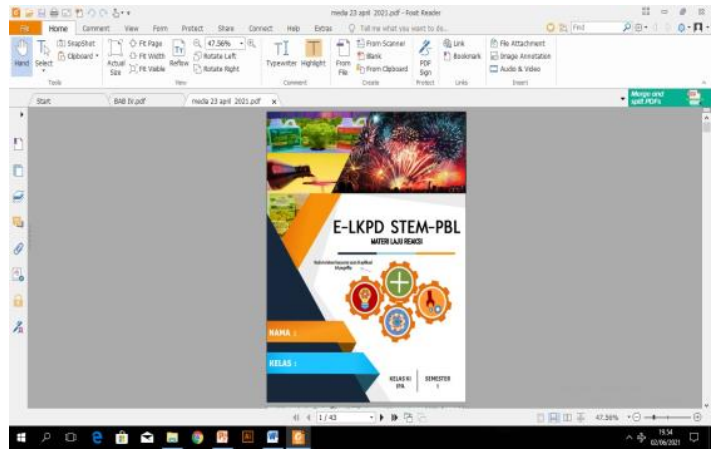

Fig 3. Initial view of the prototype in PDF

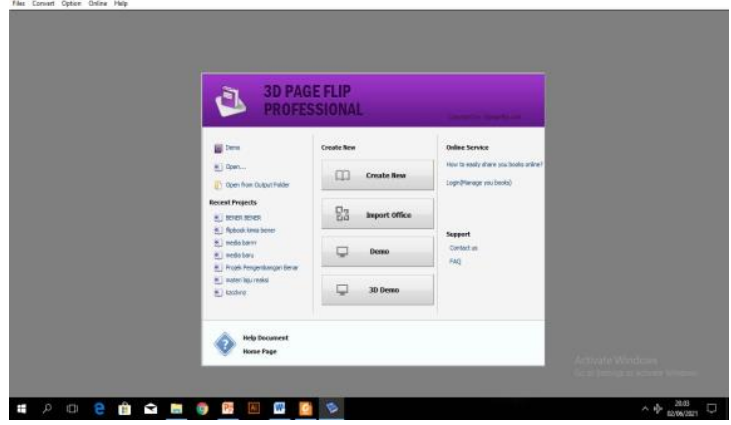

Fig 5. Operation Stage

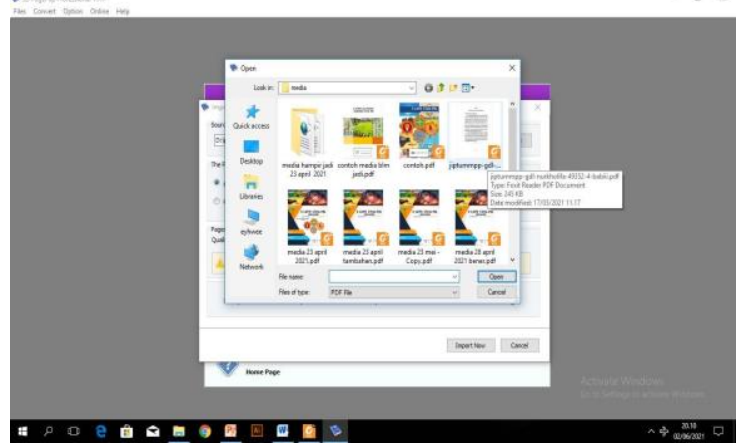

Fig 7. Selecting the E-LKPD Prototype File

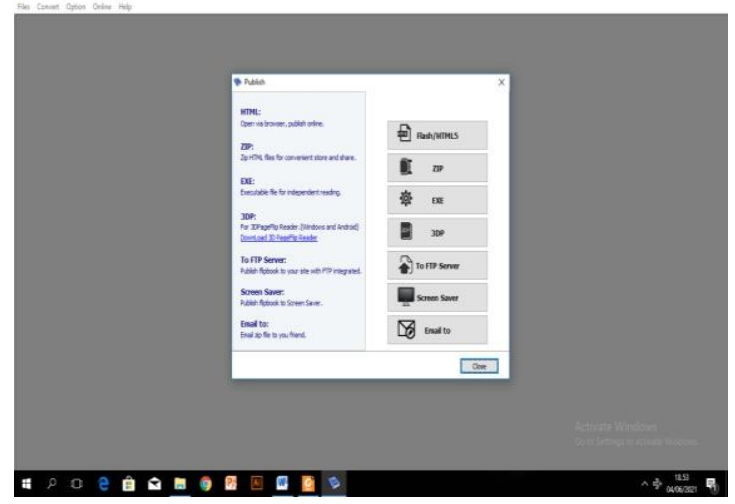

Fig 9. Process of Publishing Files into EXE format 
c. Expert team validation and revision

1. Validation and Revision of Learning Media Experts

The validation of learning media experts was carried out by Prof. Dr. rer. Nat. Muhaimin, M.Si 2 times. The first validation was carried out on April 20, 2021. From the results of the first validation, there were many shortcomings that needed to be corrected.

From the validation results above, it can be analyzed the shortcomings that must be corrected in the PBL-STEM-based E-LKPD learning media. Some of these shortcomings, the first is the use of a dark background. A dark background color will give the impression of being unenthusiastic so that it will affect the mood of the user. This is in accordance with (Purnama, 2010) which says that color is the first thing students see so that color will make an impression on the whole picture/graphic. The more harmonious the color composition used, the better the appearance of the media that will be displayed. The second is that the font and font size on each page are not appropriate. It is clear that the use of type and size of letters is not neat, giving the impression of being messy and will distract students' attentio. The three names to explain the picture are still unclear, this can be seen on page 4 of the e-lkpd. Fourth, the location of the pictures that are not appropriate and not too many pictures so that the focus of students is not divided. Finally, there must be the addition of videos and animations into the learning media. According to (Khairani, 2019) interestingly displayed learning videos can help students understand the learning material that will be delivered, and make it easy for students to be accessed at any time.

From the results of the analysis, the developer can revise the e-lkpd product for 6 days. after the developer corrected the shortcomings described above, the developer re-validated the media expert on April 26, 2021 and obtained results as shown in Fig 10.
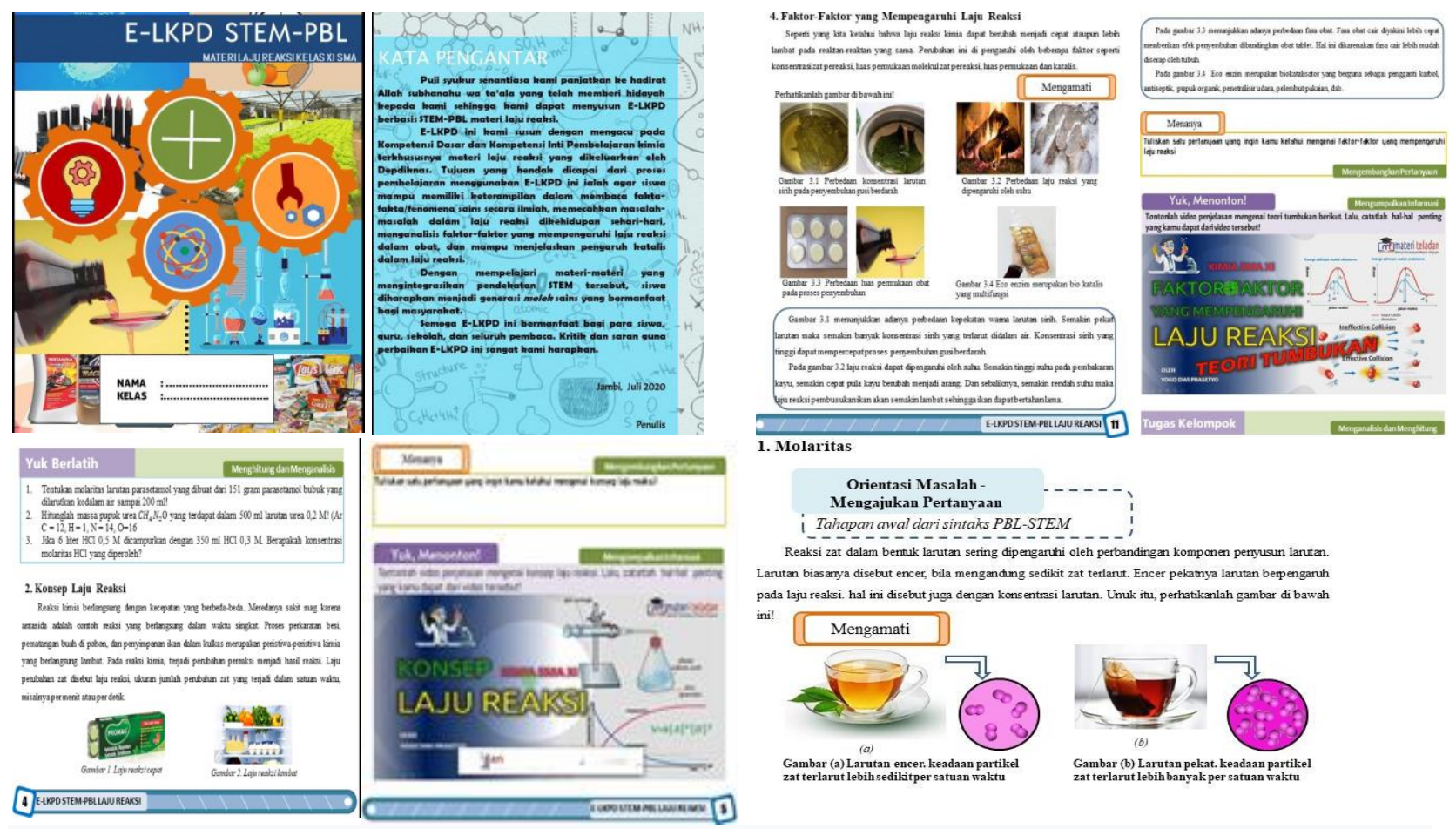

Fig 10. Validation of Learning Media Experts 
From the results of the analysis, the developer can revise the e-lkpd product for 6 days. after the developer corrected the shortcomings described above, the developer re-validated the media expert on April 26, 2021 and got the results as Table 1.

\section{Table 1}

Validation and Revision to Two Learning Media Experts

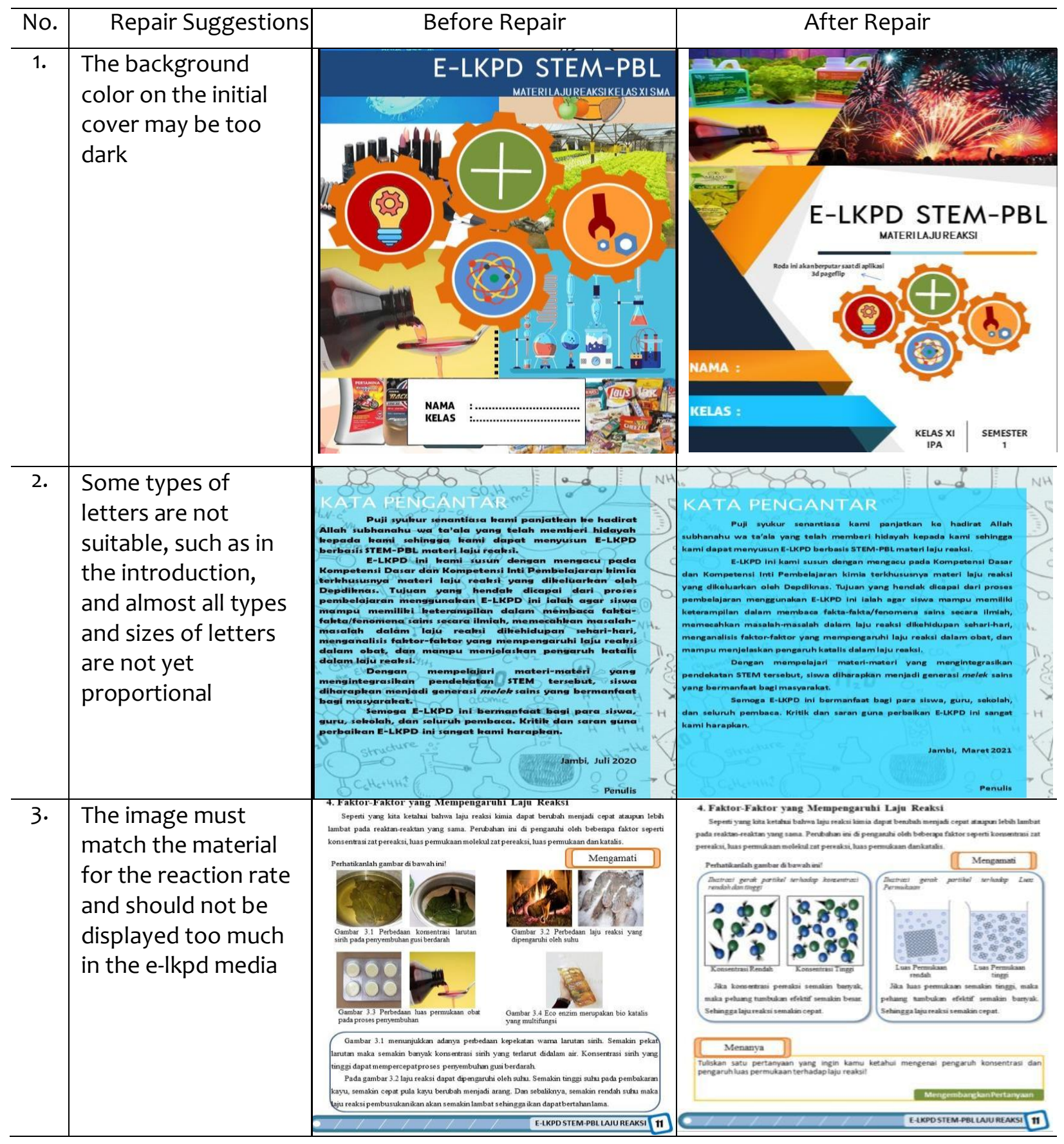




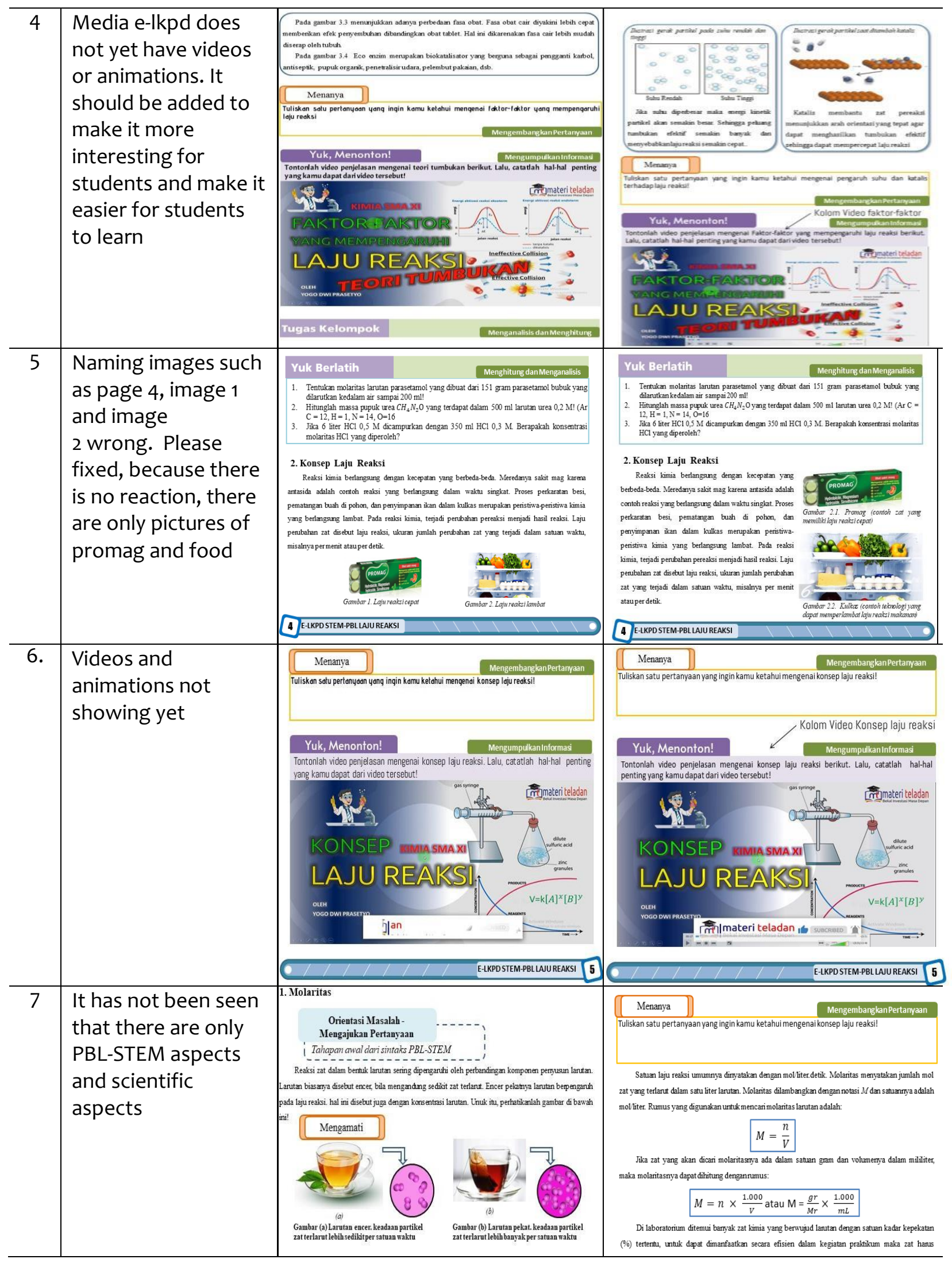


The second validation was carried out according to the advice given by media experts in the first validation. All types and sizes of letters have been adjusted and are proportional, some images have been replaced with moving animations to make it easier for students to understand, videos and animations that can support learning have been added and the explanation of the images in table 1 number 5 has been corrected according to the context of the images listed. Lee \& Owens (2004) says that effective media is media that has a simple appearance and is consistent in the use of writing and grammar styles, reciprocal and interactive, and consistent in the use of typography, graphics, color, video, audio, animation, and special effects.

\section{Validation and revision of learning material experts}

Expert validation of learning materials was carried out with Dr. Ngatijo, M.Si which was carried out 2 times. The first validation was carried out on April 19, 2021, and the results were that there were still many shortcomings in learning media. There are many shortcomings in making media, especially those related to the writing procedure and the compatibility of the questions with the material. So that this treatment was revised based on the suggestions given by the material expert opinion. Improvements are made by the developer, after that validation is carried out again which has been approved by the material expert. The following is a picture of the results of the second stage of validation (Fig 11).
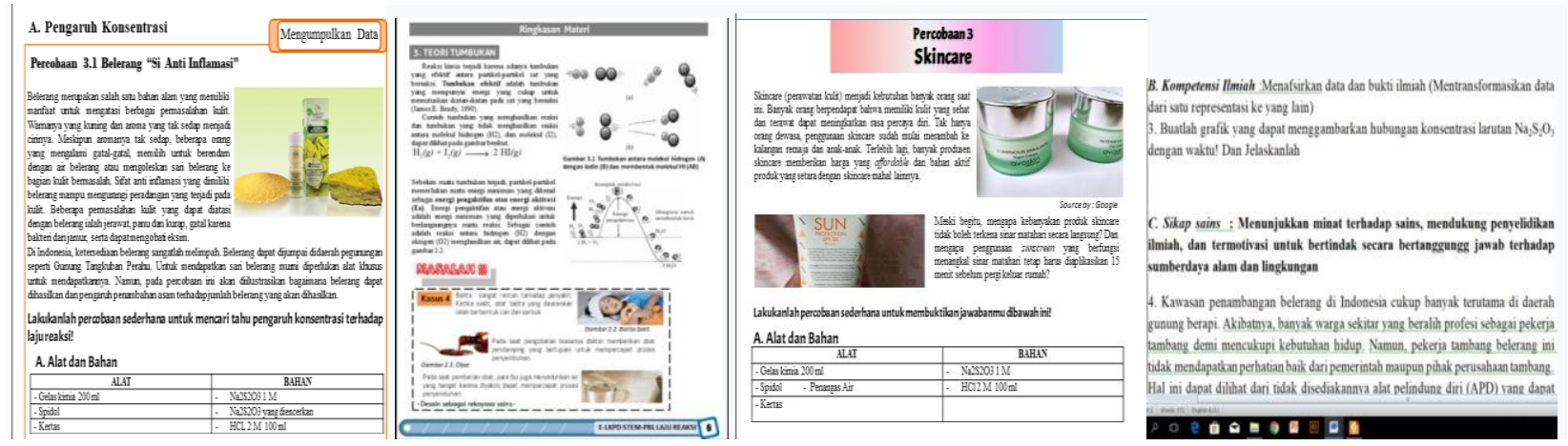

Fig 11. Validation of Learning Material Experts

The results of the second validation obtained that the learning materials contained in the e-LKPD product were in accordance with the advice given by the material expert. The revision made by the developer is the first to replace some examples of problems that are not relevant to the material for reaction rates. Problems that are not in accordance with the material being taught can lead to misunderstandings and perceptions. The second is to change the image into animation so that the material can be understood by students when studying independently. This is so that some parts of the material that require in-depth explanation can be visualized through graphics. In line with (Naufal \& Firdaus, 2019) the purpose of using animation media is to be able to explain complex material into simple ones, improve understanding of the material with the interactivity of the media, and maximize the visual effects of learning media. Finally, the questions that have been made must be loaded into the e-lkpd to make it easier for students to access. For a more complete explanation, see Appendix 12. According to Isrokijah (2015) problem-based learning helps students to 
think critically through the problems given with the aim of getting complex learning that does not only get one correct answer (Sibuea et al. 2019).

\subsection{Implementation}

At this stage, the teacher will give an assessment of the e-LKPD product that has been said to be feasible by a team of experts. This teacher assessment aims to see the effectiveness of using the product for students. The developer distributed a semi-structured questionnaire to two chemistry subject teachers who teach in class XI from the assessment given by the teacher and then analyzed. The results of the questionnaire responses from 2 chemistry teachers. From the results of the data above, then an analysis is carried out using the kappa test, and the results of the teacher's assessment on the assessment of e-lkpd products (Table 2 ).

Table 2

Assessment of 2 teachers on e-lkpd products using the kappa test

Case Processing Summary

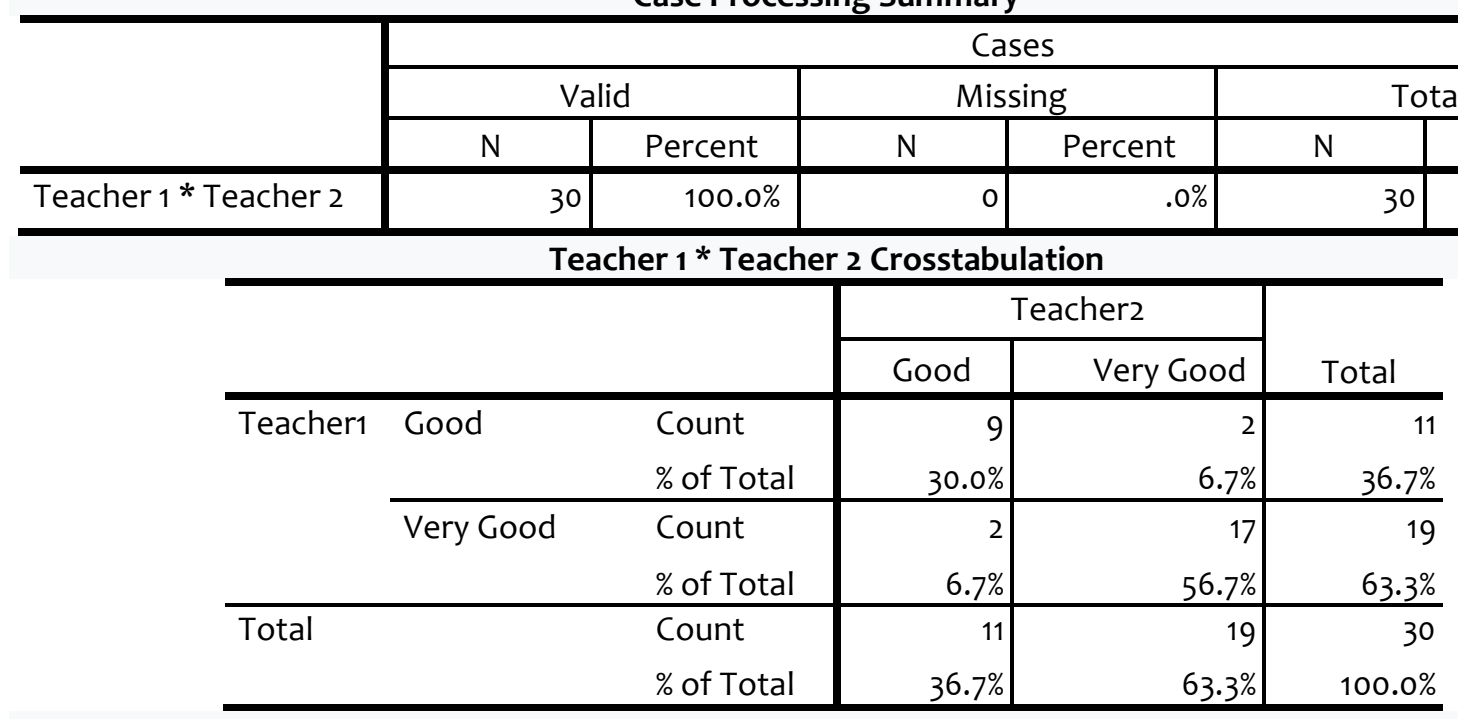

Symmetric Measures

\begin{tabular}{l|r|r|r|r}
\hline & Value & $\begin{array}{c}\text { Asymp. Std. } \\
\text { Error }^{\mathrm{a}}\end{array}$ & Approx. T & Approx. Sig. \\
\hline Measure of Agreement Kappa & .713 & .133 & 3.905 & .000 \\
N of Valid Cases & 30 & &
\end{tabular}

a. Not assuming the null hypothesis.

b. Using the asymptotic standard error assuming the null hypothesis.

The kappa test analysis table shows that there is agreement between the two teachers in assessing e-lkpd products in terms of the quality of content and objectives, instructional, and technical indicated by a kappa value of 0.713 with the "Good" category, Asymp. The tsp error indicates the smaller the value, the more reliable the measurement results. These results indicate that e-LKPD is feasible to be tested on students according to the suggestions that have been given.

\subsection{Evaluation stage}


This stage is the final stage of development research which aims to see the success of the E-LKPD products that have been developed. The evaluation is in the form of formative evaluation which is used to revise the product.

\section{a. Teacher rating}

Teacher assessment was carried out on 2 chemistry teachers because the developer wanted to see the similarity of perceptions between teacher 1 and teacher 2 . This shared perception would help developers to get more valid data. This teacher assessment questionnaire instrument contains 3 interrelated aspects, namely the Quality Aspects of Content and Objectives, Instructional Quality Aspects, and Technical Quality Aspects. The quality aspect of content and objectives contains 10 questions regarding the learning materials presented in the product. The results of this open questionnaire to teachers indicate that teacher 2 suggests changing the order of learning. Sequencing of learning must be in accordance with the syllabus. In the 2013 curriculum syllabus, the reaction rate material must first explain the collision theory and the factors that affect the reaction rate. So that the molarity is moved to the next submaterial. Then, the language used must also be improved a little more so that it is easier for students to understand.

The second aspect is the instructional quality which contains 10 questions about the learning carried out by students and teachers with the PBL-STEM-based E-LKPD media. Based on the results of questionnaires from 2 chemistry teachers, the steps for PBL learning with a STEM approach are described in the product, the problems given are in accordance with the STEM approach, and the product is able to make students independent to solve problems.

The third aspect is technical quality which contains 10 questions regarding learning media. Based on the results obtained that the media is good, the product is easy to access and use, but here there is a slight improvement regarding the font used in e-lkpd products. The teacher's suggestion is that the font used can be more varied.

From the two teacher data, the researcher conducted an agreement test on the results of the teacher's response. This test aims to see the agreement between the two teachers in assessing e-lkpd products. It can be concluded that the agreement value between the two teachers is "Good", meaning that teachers have the same perception in assessing e-LKpd products.

\section{b. Student response}

Based on the research data that the researchers presented earlier to determine the students' responses to the PBL-STEM-based e-LKpd product. The results of the study showed that the six students rated e-lkpd well. However, in the first question, 3 students thought that the vocabulary used in e-LKpd was still too difficult to understand or could lead to misunderstandings. However, students did not specify which vocabulary should be improved. Then, in number 11 it is known that 2 students are still difficult to obtain information. This could be due to the limitations of the media itself, where the reaction rate e-lkpd product is not a search engine application that can provide a lot of information to users. Although it can be run online, students also have to search for information through other platforms.

Researchers conducted a correlation test and agreement test on the results of student responses. The correlation test was conducted to determine the quantitative relationship 
between the results of the responses of students in group 1 and the results of the responses of students in group 2. Based on the results of the correlation tests carried out, the correlation value was obtained. the results of the responses of students in group 2. The agreement test aims to see the level of agreement of the two types of data. Where it can be concluded that the increase between odd and even data has an increase that is directly proportional.

\section{Conclusion}

Based on the results of development research and discussion of the development of eLKPD teaching materials based on Toulmin's argumentation pattern, the following conclusions can be drawn. The procedure for developing PBL-STEM-based e-LKPD teaching materials on the reaction rate material follows Lee Owen's design model, with the following stages: (1) The analysis includes media analysis, student characteristic analysis, technology analysis, and situation analysis, and data analysis. At this analysis stage, developers must create products that meet their needs, namely interactive (2) Design includes determining the development team, compiling a development schedule, making flowcharts and making storyboards. At this stage, developers have to learn how to make interactive media such as quizzes and animations, so that the e-LKPD that will be made later is more complete and has high use value (3) Development includes making products which are then validated by a team of experts until they are validated (4) Implementation, at this stage a product assessment is carried out by 2 chemistry teachers to see the agreement between the two teachers on the product developed through the kappa test, one-on-one trial with 2 groups of respondents consisting of 3 students in each group, small group trial with two groups of respondents carried out at MAN 2 Jambi City. This trial is not done face-to-face face-to-face, but online (5) Evaluation, which is carried out at each stage is ongoing.

\section{References}

AAPS. (1989). A question worth science for all Americans. The American Physiological Society.

Abubakar, A. B., \& Arshad, M. Y. (2015). Self-directed learning and skills of problem-based learning: A case of Nigerian secondary schools chemistry students. International Education Studies, 8(12), 7078. Doi:10.5539/ies.v8n12p70

Afriana, J., Permanasari, A., \& Fitriani, A. (2016). Project based learning integrated to stem to enhance elementary school's students scientific literacy. Jurnal Pendidikan IPA Indonesia, 5(2), 261-267. DOI:10.15294/jpii.v5i2.5493

Apriliyanti, W. (2019). Pengembangan E-LKPD berpendekatan pembelajaran STEM (Science, Technology, Enginering, and mathematic) pada materi koloid untuk meningkatkan kreatifitas siswa. Universitas Jambi.

Ariani, L., Sudarmin, S., \& Nurhayati, S. (2019). Analisis berpikir kreatif pada penerapan problem based learning berpendekatan science, technology, engineering, and mathematics. Jurnal Inovasi Pendidikan Kimia, 13(1), 2307-2317.

Birgili, B. (2015). Creative and critical thinking skills in problem-based learning environments. Journal of Gifted Education and Creativity, 2(2), 71-80. DOI: 10.18200/JGEDC.2015214253

Boud, D. (1993). Experience as the base for learning. Higher Education Research and Development, 12(1), 33-44. DOI: 10.1080/0729436930120104 
Dischino, M., DeLaura, J. A., Donnelly, J., Massa, N. M., \& Hanes, F. (2011). Increasing the STEM pipeline through problem-based learning. Technology Interface International Journal, 12(1), 21-29.

Fakhriyah, F., Roysa, M., \& Masfuah, S. (2017). Analisis kemampuan konsep sains ditinjau dari aspek literasi sains mahasiswa progdi pendidikan guru sekolah dasar.

Fitriani, D. E. N., Amelia, E., \& Marianingsih, P. (2017). Penyusunan modul pembelajaran berbasis sains teknologi dan masyarakat (stm) pada konsep bioteknologi (Sebagai Bahan Ajar Siswa SMA Kelas XII). Biosfer: Jurnal Pendidikan Biologi, 10(2), 60-72. DOI:10.21009/biosferjpb.10-2.8

Fitriyani, D., Jalmo, T., \& Yolida, B. (2019). Penggunaan problem based learning untuk meningkatkan keterampilan kolaborasi dan berpikir tingkat tinggi. Jurnal Bioterdidik: Wahana Ekspresi Ilmiah, 7(3), 77-87.

Hakimah, N., Muchson, M., Herunata, H., Permatasari, M. B., \& Santoso, A. (2021). Identification student misconceptions on reaction rate using a Google forms three-tier tests. AIP Conference Proceedings, 2330(1), 020020. DOI:10.1063/5.0043114

Hmelo-Silver, C. E. (2004). Problem-based learning: What and how do students learn? Educational Psychology Review, 16(3), 235-266. DOI:10.1023/B:EDPR.0000034022.16470.f3

Iftitahurrahimah, I., Andayani, Y., \& Al Idrus, S. W. (2020). Pengaruh model problem based learning (pbl) terhadap kemampuan komunikasi siswa materi pokok larutan elektrolit dan non-elektrolit. Jurnal Pijar Mipa, 15(1), 7-12. DOI:10.29303/jpm.v15i1.1289

Imaningtyas, C. D., Karyanto, P., Nurmiyati, N., \& Asriani, L. (2016). Penerapan e-module berbasis problem based learning untuk meningkatkan literasi sains dan mengurangi miskonsepsi pada materi ekologi siswa kelas x mia 6 sman 1 Karanganom tahun pelajaran 2014/2015. Bioedukasi: Jurnal Pendidikan Biologi, 9(1), 4-10.

Isrokijah, I. (2015). Developing problem-based learning ( $P B L)$ worksheets for the eight grade students at junior high school. LLT Journal: A Journal on Language and Language Teaching, 18(2), 99-106. DOI:10.24071/llt.2015.180203

Khairani, S. (2019). Pengembangan Media Pembelajaran Menggunakan Pendekatan Realistik Berbantuan Geogebra Untuk Meningkatkan Kemampuan Spasial Matematis Siswa Smp [PhD Thesis]. Unimed.

Laili, I. (2019). Efektivitas pengembangan e-modul project based learning pada mata pelajaran instalasi motor listrik. Jurnal Imiah Pendidikan dan Pembelajaran, 3(3), 306-315.

Lee, C.-D. (2014). Worksheet usage, reading achievement, classes' lack of readiness, and science achievement: A cross-country comparison. International Journal of Education in Mathematics, Science and Technology, 2(2). DOI:10.18404/ijemst.38331

Lee, W. W., \& Owens, D. L. (2004). Multimedia-based instructional design: Computer-based training, web-based training, distance broadcast training, performance-based solutions. John Wiley \& Sons.

Malan, S. B., \& Ndlovu, M. (2014). Introducing problem-based learning (PBL) into a foundation programme to develop self-directed learning skills. South African Journal of Education, 34(1). DOI: 10.15700/201412120928

McDowell, E. T., \& Waddling, R. E. L. (1985). Improving the design of laboratory worksheets. Journal of Chemical Education, 62(11), 1037. DOI:10.1021/edo62p1037

Mujasam, M., Widyaningsih, S. W., \& Yusuf, I. (2018). Effect of cooperative learning model types of stick talking using simple props to higher order thinking skill. Kasuari: Physics Education Journal (KPEJ), 1(2), 73-82. DOI:10.37891/kpej.v1i2.27

Nadhifatuzzahro, D., Setiawan, B., \& Sudibyo, E. (2015). Kemampuan literasi sains siswa kelas VII-B SMP Negeri 1 Sumobito melalui pembuatan jamu tradisional. Seminar Nasional Fisika dan Pembelajarannya, 21-27.

Naufal, M., \& Firdaus, M. (2019). Penerapan animasi 3 dimensi untuk wisata edukasi anak berbasis virtual reality. Jurnal Teknologi Elekterika, 16(1), 33-38. DOI:10.31963/elekterika.v16i1.2003 
OECD. (2018). What 15-year-old students in Indonesia know and can do. O. Programme for International Student Assessment (PISA) Result from PISA 2018, 1-10. http://www.oecd.org/pisa/ Data

Ogunkola, B. J. (2013). Scientific literacy: Conceptual overview, importance and strategies for improvement. Journal of Educational and Social Research, 3(1), 265-274.

Purnama, S. (2010). Elemen warna dalam pengembangan multimedia pembelajaran agama Islam. AlBidayah: Jurnal Pendidikan Dasar Islam, 2(1). DOI:10.14421/al-bidayah.v2i1.102

Rahayu, M. (2015). Pelaksanaan standar pengelolaan pendidikan di sekolah dasar kecamatan Ngemplak, Sleman. Jurnal Penelitian Ilmu Pendidikan, 8(1), 62-79.

Saija, M. (2019). Profil kemampuan literasi kimia siswa SMA Negeri 3 Ambon. Jurnal Kiprah, 7(2), 99106. DOI:10.31629/kiprah.v7i2.1463

Sariati, D. (2013). Analisis keterampilan proses pada penggunaan Hierarki Inkuiri dan dampaknya terhadap literasi sains siswa SMP [PhD Thesis]. Universitas Pendidikan Indonesia.

Setiyani, R. (2010). Pemanfaatan internet sebagai sumber belajar. Dinamika Pendidikan, 5(2), 117-133.

Sibuea, G. V., Suyanti, R. D., \& Silaban, S. (2019). The development of chemistry lab guide book for high school based on guided inquiry to measure scientific attitudes and science process skill. Proceedings of The 4th Annual International Seminar on Transformative Education and Educational Leadershi, 319-325.

Silaban, S. (2021). Pengembangan program pengajaran. Medan: Yayasan Kita Menulis.

Valdez, J. E., \& Bungihan, M. E. (2019). Problem-based learning approach enhances the problem solving skills in chemistry of high school students. JOTSE, 9(3), 282-294. DOI:10.3926/jotse.631

Yuliati, L., Hapsari, A. A., Nurhidayah, F., \& Halim, L. (2018). Building scientific literacy and physics problem solving skills through inquiry-based learning for STEM education. Journal of Physics: Conference Series, 1108(1), 012026. DOI:10.1088/1742-6596/1108/1/012026 